\title{
THE EXCRETION OF ALBUMIN AND GLOBULIN IN NEPHRITIS
}

\author{
By ALMA HILLER, J. F. MCINTOSH AND DONALD D. VAN SLYKE
}

(From the Hospital of the Rockefeller Institute for Medical Research, New York)

(Received for publication January 14, 1927)

The present work was undertaken in order to ascertain whether the nature of the protein mixture excreted in the different types of nephritis is related to the type and severity of the disease.

\section{HISTORICAL}

A summary of the early literature on the relation of albumin to globulin excretion in the urine of nephritic patients has been given by Senator (1) and by Cloetta (2). A general survey of the literature has been given given more recently by Geill (3). Hoffman was the first to take up the work in detail. Using the early gravimetric methods in 1882 (4) he reported that any albumin : globulin ratio may occur in any type of nephritis, and the value of the ratio is dependent not upon the type of change in the kidney, but on the intensity of the disease processes. A low ratio signified a severe condition, a high ratio a mild one. The ratio was found to rise with recovery in acute nephritis. Lecorché and Talamon (5) found the ratio to decrease with increased severity of the disease. Csatáry (6) found great fluctuations in the albumin : globulin ratio, but made a general statement that he found ratios below 1 in cases of amyloid kidney and above 10 in cases of contracted kidney. In severe cases the ratio fell. Cloetta (2) confirmed the work of Csatáry and reported low ratios in acute nephritis, with rise on recovery, and ratios usually over 10 in chronic nephritis. He found no relation between the albumin : globulin ratios in urine and in serum. Joachim (7) reported a low ratio in amyloid kidney, a high ratio in contracted kidney. A rise in the ratio signified a good prognosis while a fall signified a poor prognosis. Paton (8) reported albumin fractions high in chronic nephritis and low in acute cases. He was unable to find high globulins in amyloid kidney, and was unable to form any conclusions on the relation of the urinary ratio to that of plasma. Dreser (9) reported that the ratio has no diagnostic importance. Gross (10) reported that the ratio varied and had no prognostic or diagnostic value. Strauss (11) reported that the ratio had no diagnostic value, and that it was mostly so different from that of serum that one would be led to believe that the protein excretion is a selective process of the glomerulus. Wallis (12) re- 
ported a low ratio in functional albuminuria and "leaky kidney," and a ratio of 6 in chronic and in toxic nephritis. Autenrieth (13) found a distinct prognostic value in the albumin : globulin ratio. In agreement with Hoffman (4) he found ratios under 5 to the accompanied by a poor prognosis.

The relation of urinary protein excretion to plasma protein concentration has been studied by a number of authors. Kisch (14) showed that when the total protein excretion was less than 1 gram per liter the total plasma protein was over 7 per cent. When the protein excretion increased, the plasma proteins fell below 7 per cent. Linder, Lundsgaard and Van Slyke (15) found that when the protein excretion exceeded 1 gram per day there was a reduction of the total concentration of protein and of the albumin : globulin ratio in the plasma, the plasma loss affecting chiefly the albumin. Kollert and Starlinger (16) found that when the amount of protein excreted exceeded 1 gram per liter of urine the serum protein fell below 8 per cent, and continued to fall with increased excretion. The serum albumin showed a progressive fall in the same manner, with increased protein excretion. In the case of globulin, however, it was found that the higher the globulin fraction rose in the serum the higher the percentage of globulin in the proteins excreted in the urine, so that the albumin : globulin ratio in the urine tended to decrease with the fall in the ratio in the serum.

\section{METHOD FOR THE DETERMINATION OF PROTEINS IN URINE ${ }^{1}$}

Albumin and globulin were separated by precipitating the latter with sodium sulfate, as in Howe's (17) technique for plasma protein separation. The separated proteins were determined by the colorimetric method of Autenrieth $(13,18)$ which depends on the development of the biuret color by proteins treated with copper sulfate and alkali.

The chief disadvantages of the Autenrieth method have been the lack of satisfactory standards, and the tedious technique of precipitating and washing the proteins. We have found that standards may be prepared from solutions of pure biuret. One milligram of Kahlbaum's biuret was found to give a color equal to that produced by $0.924 \mathrm{mgm}$. of either albumin or total urinary protein. This biuret equivalent of the proteins was obtained by comparison of Kjeldahl and colorimetric determinations on a number of urines. Instead of precipitating with heat and acid we have precipitated the proteins with trichloracetic acid, and have centrifuged instead of washing on a filter.

${ }^{1}$ A preliminary note on the method has been published in the Proc. Soc. Exp. Biol. Med., 1927, xxiv, 385. 
Magnesium sulfate was also tested for the precipitation of the globulins. Saturation with magnesium sulfate was found to give a greater precipitation of protein than did 22 per cent sodium sulfate. The presence of magnesium sulfate also decreases the depth of the color somewhat in the end reaction: it was necessary to remove the magnesium by precipitating the albumin twice with trichloracetic acid.

Since sodium sulfate gave a filtrate with a biuret equivalent of albumin equal to that of total protein, and since this same precipitant is used for the routine separation of the proteins in the plasma by Howe's method, we adopted sodium sulfate for precipitation of the urine globulins.

Reagents:

10 per cent trichloracetic acid solution.

3 per cent sodium hydroxide solution.

30 per cent sodium hydroxide solution.

20 per cent copper sulfate solution, containing 20 grams $\mathrm{CuSO}_{4} \cdot 5 \mathrm{H}_{2} \mathrm{O}$ per $100 \mathrm{cc}$. solution.

44 per cent sodium sulfate solution containing 44 grams anhydrous

$\mathrm{Na}_{2} \mathrm{SO}_{4}$ per 100 cc. solution. This solution is saturated at $37^{\circ}$ and must be kept at that temperature to prevent crystallization. The sodium sulfate solution must be neutral to litmus.

Standard biuret solution: Dissolve 0.4000 gram of biuret in distilled water, and dilute to a volume of $150 \mathrm{cc}$. This solution will keep in the ice box at least a month.

Preparation of urine samples: Adjust a portion of urine (50 to 200 cc.) to a $\mathrm{pH}$ of about 7.4 ; i.e., slightly alkaline to sensitive litmus paper. The reaction may be adjusted with more certainty by removing drops and testing with phenol red. Filter if not perfectly clear. This same specimen can now be used for the precipitation of globulin and for total protein.

Total protein: Measure $2 \mathrm{cc}$. of the specimen into a graduated centrifuge tube, add an equal volume of 10 per cent trichloracetic acid, mix with a narrow glass rod, and centrifuge 5 minutes. If the volume of precipitate is between 0.2 and $0.6 \mathrm{cc}$., the amount of protein in it can be read against the standard described below, and the analysis is continued as described in the next paragraph. If the 
volume of precipitate is larger or smaller, a second precipitation is performed, with enough urine to yield a precipitate of between 0.2 and $0.6 \mathrm{cc}$.

Pour off the supernatant fluid, draining as dry as possible. Dissolve the precipitate in about $3 \mathrm{cc}$. of 3 per cent sodium hydroxide solution and wash into a $10 \mathrm{cc}$. graduated cylinder with portions of the 3 per cent sodium hydroxide until the volume has reached about $9 \mathrm{cc}$. Add $0.25 \mathrm{cc}$. of 20 per cent copper sulfate solution, dilute to $10 \mathrm{cc}$. with 3 per cent sodium hydroxide. Mix thoroughly by shaking, let stand 10 minutes, centrifuge, and compare the supernatant fluid in a colorimeter against a standard prepared at the same time.

To prepare the standard color solution measure $5 \mathrm{cc}$. of the standard biuret solution, containing $13.33 \mathrm{mgm}$. of biuret, equivalent to 12.3 mgm. of protein, into a $10 \mathrm{cc}$. graduated cylinder. Add distilled water to $8 \mathrm{cc}$, add $1 \mathrm{cc}$. of 30 per cent sodium hydroxide, $0.25 \mathrm{cc}$. of 20 per cent copper sulfate solution, then dilute to $10 \mathrm{cc}$. with water. Mix thoroughly, let stand 10 minutes, centrifuge. Transfer the supernatant fluid to the colorimeter cup, and compare with the solution of urine protein, setting the depth of the standard column at $15 \mathrm{~mm}$.

Calculation:

Grams protein per liter urine $=\frac{15}{R} \times \frac{12.3}{\text { cc. urine used }}$

$$
=\frac{184.5}{R \times(\text { cc. urine used })}
$$

$R$ being the depth of the protein solution matching $15 \mathrm{~mm}$. of the standard.

Precipitation of globulin: To $10 \mathrm{cc}$. of urine prepared as described above, add $10 \mathrm{cc}$. of 44 per cent sodium sulfate solution, mix well, and place in an incubator at $37^{\circ} \mathrm{C}$. for 3 hours. Filter until a perfectly clear filtrate is obtained.

Albumin: With the filtrate from the sodium sulfate precipitation proceed as described under "total protein," performing the precipitation tentatively with a volume of filtrate equal to 4 -fold that of the urine taken for total protein determination. 


\section{Calculation:}

Grams albumin per liter urine $=\frac{15}{R} \times \frac{12.3 \times 2}{\text { cc. filtrate used }}$

$$
=\frac{369}{R \times(\text { cc. filtrate used })}
$$

Globulin: The globulin is estimated by difference.

$$
\text { (Total protein) }- \text { (albumin })=\text { (globulin) }
$$

The maximum error of the method is about \pm 1 per cent for total protein and for albumin.

\section{Experiments on globulin precipitation}

In order to determine the solubility of globulin in 22 per cent sodium sulfate, globulin was prepared from horse serum according to the

TABLE 1

Solubility of globulin in 22 per cent sodium sulfate solution

\begin{tabular}{c|c|c}
\hline Solution number & Strength of globulin solution & Amount of protein in filtrate \\
\cline { 2 - 3 } 1 & per cent & per cent \\
2 & 0.52 & 0.011 \\
& 1.56 & 0.016 \\
\hline
\end{tabular}

method described by Haslam (19). Two solutions were tested. Solution 1 contained 0.52 per cent globulin. Solution 2 contained 1.56 per cent globulin. To each was added an equal volume of 44 per cent sodium sulfate, so that the precipitating mixture, contained 22 per cent of sodium sulfate. The procedure was carried out as described in the method for urine. The filtrate was analyzed for nitrogen by Kjeldahl. The results are shown in table 1 .

From the results one may estimate that the amount of actual globulin in solution in the filtrate is 0.009 per cent, 0.002 per cent of impurity (presumably albumin) being dissolved in the filtrate when the 0.52 per cent globulin solution was precipitated, and 0.007 per cent when the 1.56 per cent solution was precipitated. We have, however, not corrected our results for this solubility, as it is too small to affect their significance. 
To test whether the precipitation of globulin by 22 per cent sodium sulfate at $37^{\circ} \mathrm{C}$. is complete in 3 hours, comparative determinations were made, allowing the precipitating mixture to stand 3 hours and 24 hours. Agreement was good, as is shown in table 2.

TABLE 2

Effect of precipitation time at $37^{\circ} \mathrm{C}$. on globulin estimation

\begin{tabular}{c|c|c}
\hline & \multicolumn{2}{|c}{ Amount of globulin per liter } \\
\cline { 2 - 3 } Determination number & \multicolumn{2}{|c}{ Incubation time } \\
\cline { 2 - 3 } & 3 hours & 24 hours \\
\hline 1 & grams & grams \\
2 & 3.8 & 3.6 \\
3 & 2.6 & 2.6 \\
& 2.4 & 2.4 \\
\hline
\end{tabular}

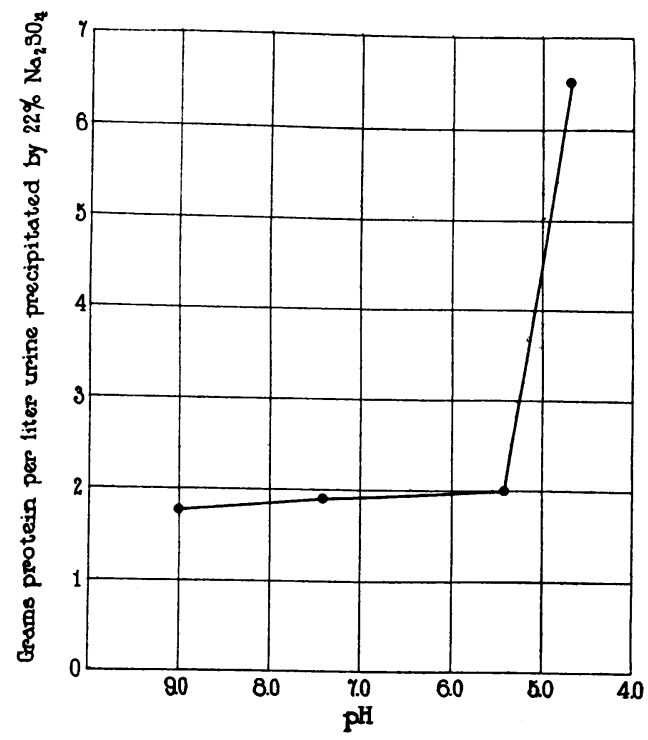

Fig. 1. The Effect of pH of Urine on the Precipitation of Globulin

In order to test the optimum reaction for the precipitation of globulin with sodium sulfate, portions of urine were adjusted to $\mathrm{pH} 9$, $7.4,5.4$, the isoelectric point of serum globulin, and 4.7, the iso- 
electric point of serum albumin. Figure 1 shows that between the isoelectric point of globulin and $\mathrm{pH} 9.0$ the precipitation of protein is practically constant, while at the isoelectric point of albumin the amount of protein precipitated increases. For this reason the acid urines were adjusted to the alkaline side of neutrality.

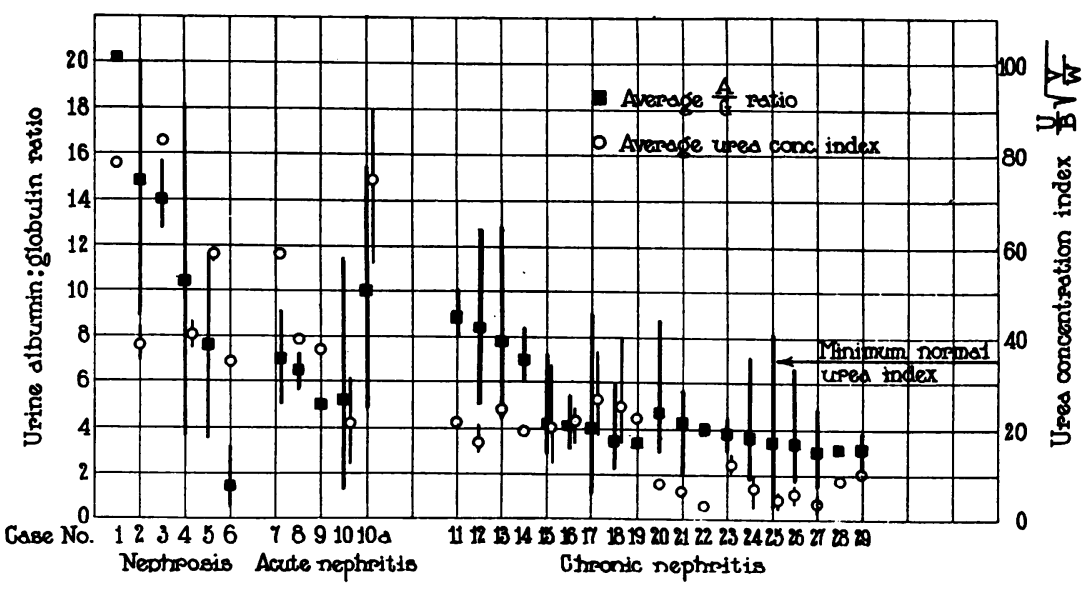

Fig. 2. Summary of Cases Classified According to Urine Albumin : Globuin Ratios aND UREA Concentration INDEX

For each patient a solid square indicates the average albumin : globulin ratio during the observation period; the line running through the square indicates the extreme range of ratio found. The open circle indicates the average urea concentration index, $\frac{U}{B} \sqrt{\frac{V}{W}}$, for a patient; the line running through the circle indicates the range of fluctuation of the index during the period of observation.

\section{OBSERVATIONS IN NEPHRITIS}

In a series of nephritic cases the urinary proteins were estimated by the above method. The plasma proteins were estimated by the method of Howe (17). Blood urea nitrogen was estimated by the method of Van Slyke and Cullen (20). Blood creatinine was estimated by the method of Folin and Wu (21).

The urea concentration index was calculated from the urea content of blood and urine by a modification of the original method of Austin, Stillman, and Van Slyke. The present index is calculated as $\frac{U}{B} \sqrt{\frac{V}{W}}$ 
and has been discussed in a previous publication (22). $U=$ urine urea concentration. $B=$ blood urea concentration. $V=$ urine volume output in cc. per hour. $W=$ body weight. The index represents the number of times the blood urea is concentrated in the urine when $\frac{V}{W}=1$, or the volume output is $1 \mathrm{cc}$. per hour per kilo (e.g., 60 cc. per hour for a 60 kilo person), which is the average normal output. When $\frac{V}{W}=1$ the simple concentration ratio $\frac{U}{B}$ represents

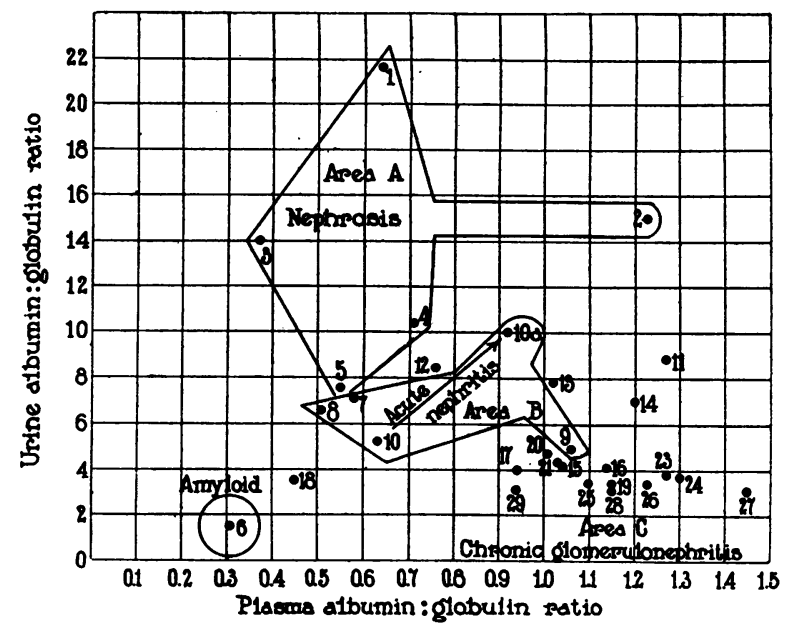

Fig. 3. Relation of the Average Albumnn-Globulin Ratio of Urine to That of Blood Plasma

The numbers are those of the cases shown in table 4. The arrow between 10 and $10 \mathrm{a}$ indicates the direction of change in case 10 during recovery.

the concentration index. With a urine of greater volume, $U$ is naturally less, and is multiplied by the empirical volume factor $\sqrt{\frac{V}{W}}$ in order to bring it up to the value it would have when $\frac{V}{W}=1$.

The results are shown in tables 3,4 , and 5, and figures 2 and 3. The types of nephritis are classified according to Volhard and Fahr as outlined by Linder, Lundsgaard, and Van Slyke (15).

The cases of nephrosis (tables 3 and 4 and figure 2) with one ex- 
ception had high urine albumin: globulin ratios, mostly above 10 . The urea concentration index was normal or high in all these cases, and the blood urea nitrogen was below 0.20 gram per liter.

Case no. 6, figures 2 and 3 and table 4, with a urinary albumin : globulin ratio of only 1.5 was not a pure nephrosis, but was complicated with pulmonary tuberculosis and amyloidosis. It has been pointed out by other authors $(6,7,23)$ that amyloid degeneration is associated with a high output of globulin, resulting in a low albumin : globulin ratio in the urine. Csatáry (6) reported ratios below 1. Joachim (7) reported a ratio of 1.4. Gross (10) found ratios varying from 0.5 to 5 . Our results showed a constantly low urinary albumin : globulin ratio, ranging from 0.5 to 3.1 , and averaging 1.5 .

TABLE 3

The albumin : globulin ratio in the urine in different types of nephritis

\begin{tabular}{|c|c|c|c|c|c|c|}
\hline Classification & $\begin{array}{l}\text { Number } \\
\text { of cases } \\
\text { examined }\end{array}$ & $\begin{array}{c}\text { Number } \\
\text { having } \\
\text { A:G ratio } \\
\text { above } 10\end{array}$ & $\begin{array}{c}\text { Number } \\
\text { having } \\
\text { A: G ratio } \\
\text { between } \\
5 \text { and } 10\end{array}$ & $\begin{array}{c}\text { Number } \\
\text { having } \\
\text { A:G ratio } \\
\text { below } 5\end{array}$ & $\begin{array}{c}\text { Number hav- } \\
\text { ing blood } \\
\text { urea nitrogen } \\
\text { below } 0.20 \\
\text { gram per liter }\end{array}$ & $\begin{array}{c}\text { Number hav- } \\
\text { ing blood } \\
\text { urea nitrogen } \\
\text { above } 0.20 \\
\text { gram per liter }\end{array}$ \\
\hline Nephrosis....... . & 6 & 4 & 1 & $1^{*}$ & 6 & $\mathbf{0}$ \\
\hline Nephritis, acute........ & 4 & 0 & 4 & 0 & 3 & 1 \\
\hline Nephritis, chronic....... & 19 & 0 & 4 & 15 & 5 & 14 \\
\hline
\end{tabular}

* Complicated with pulmonary tuberculosis and amyloidosis. See discussion.

The four cases of acute nephritis (tables 3 and 4 and figure 2) had urine albumin : globulin ratios between 5 and 10 . Only one case, no. 10, was observed during the whole course of the disease, and the results of this case can be distinctly classed into two groups (tables 4 and 5 and figures 2 and 3). The early stage of the disease was characterized by an average urinary albumin : globulin ratio of 5, and an average urea concentration index of 21 . The period of recovery (10a, table 4 , and figures 2 and 3 ) showed an average ratio of 10 and an average urea concentration index of 74 . The blood urea nitrogen was at all times below 0.20 gram per liter. The remaining cases observed had normal urea concentration indices and blood urea.

Of the 19 cases of chronic nephritis observed, 4 had urinary albumin : globulin ratios between 5 and 10, while 15 had ratios below 5 (tables 3 and 4 , and figure 2 ). The ratios roughly paralleled the 
TAB

Summary

\begin{tabular}{|c|c|c|c|c|c|c|c|c|c|c|c|}
\hline \multirow[b]{2}{*}{ 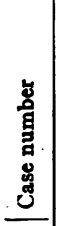 } & \multirow[b]{2}{*}{ Initials } & \multirow[b]{2}{*}{ Diagnosis } & \multirow[b]{2}{*}{ Age } & \multicolumn{3}{|c|}{ Plasma proteins } & \multicolumn{4}{|c|}{$\begin{array}{l}\text { Urine proteins average figures } \\
\text { per } 24 \text { hours }\end{array}$} & \multirow{2}{*}{$\begin{array}{c}\text { Average } \\
\text { urea } \\
\text { concentra. } \\
\text { tion index } \\
\frac{U}{\bar{B}} \sqrt{\bar{V}}\end{array}$} \\
\hline & & & & 夏 & 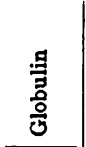 & $\stackrel{\ddot{4}}{\ddot{4}}$ & 冒 & 禀 & 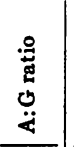 & 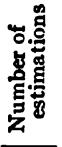 & \\
\hline & & & years & per cent & per cent & & grams & grams & & & \\
\hline 1 & W. J. & Nephrosis & 27 & 1.65 & 2.21 & 0.75 & 15.1 & 0.7 & 21.6 & 2 & 78.0 \\
\hline 2 & G. G. & Nephrosis & 24 & 2.40 & 2.04 & 1.18 & 7.5 & 0.5 & 14.9 & 3 & 37.8 \\
\hline 3 & B. S. & Nephrosis & 12 & 1.02 & 2.75 & 0.37 & 4.2 & 0.3 & 14.0 & 4 & 82.6 \\
\hline 4 & M. R. & Nephrosis & 29 & 1.83 & 2.50 & 0.73 & 13.5 & 1.3 & 10.4 & 6 & 39.8 \\
\hline 5 & B. B. & Nephrosis & 23 & 1.46 & 2.47 & 0.59 & 9.9 & 1.3 & 7.6 & 8 & 58.0 \\
\hline 6 & G. D. & $\begin{array}{l}\text { Nephrosis, amyloido- } \\
\text { sis, acute pulmo- } \\
\text { nary tuberculosis }\end{array}$ & 57 & 1.15 & 3.37 & 0.34 & 8.4 & 5.6 & 1.5 & 17 & 34.2 \\
\hline 7 & A. C. & Nephritis, acute & 27 & 1.55 & 2.68 & 0.58 & 6.4 & 0.9 & 7.1 & 2 & 57.6 \\
\hline 8 & J. My. & Nephritis, acute & 24 & 1.38 & 2.72 & 0.51 & 11.2 & 1.7 & 6.6 & 3 & 39.4 \\
\hline 9 & B. Bl. & Nephritis, acute & 34 & 2.98 & 2.82 & 1.06 & 2.9 & 0.6 & 4.8 & 2 & 37.3 \\
\hline 10 & D. G. & Nephritis, acute & 30 & 1.54 & 2.55 & 0.60 & 12.8 & 2.5 & 5.2 & 8 & 20.7 \\
\hline $10 \mathrm{a}$ & D. G. & Nephritis, acute & 30 & 2.45 & 2.75 & 0.89 & 7.0 & 0.7 & 10.0 & 6 & 73.7 \\
\hline 11 & R. V. & Nephritis, chronic & 24 & 2.08 & 1.64 & 1.27 & 15.1 & 1.7 & 8.9 & 3 & 21.0 \\
\hline 12 & P. L. & Nephritis, chronic & 28 & 1.98 & 2.61 & 0.76 & 5.0 & 0.6 & 8.4 & 3 & 16.9 \\
\hline 13 & M. McC. & Nephritis, chronic & 20 & 2.01 & 3.23 & 0.62 & 3.9 & 0.5 & 7.8 & 3 & 23.5 \\
\hline 14 & E. W. & Nephritis, chronic & 25 & 2.59 & 2.13 & 1.20 & 3.5 & 0.5 & 7.0 & 3 & 18.8 \\
\hline 15 & J. L. & Nephritis, chronic & 16 & 2.05 & 1.96 & 1.04 & 6.7 & 1.6 & 4.2 & 9 & 20.2 \\
\hline 16 & R. N. & Nephritis, chronic & 37 & 2.07 & 1.82 & 1.14 & 8.2 & 2.0 & 4.1 & 4 & 21.1 \\
\hline 17 & B. F. & Néphritis, chronic & 24 & 1.77 & 2.08 & 0.85 & 3.2 & 0.8 & 4.0 & 8 & 26.3 \\
\hline 18 & S. J. & Nephritis, chronic & 34 & 1.90 & 3.64 & 0.52 & 2.8 & 0.8 & 3.5 & 5 & 24.7 \\
\hline 19 & M. G. & Nephritis, chronic & 12 & 2.85 & 2.57 & 1.03 & 1.4 & 0.4 & 3.5 & 2 & 22.2 \\
\hline 20 & E. L. & Nephritis, chronic & 33 & 2.96 & 2.92 & 1.01 & 4.7 & 1.0 & 4.7 & 6 & 7.4 \\
\hline 21 & E. Rt. & Nephritis, chronic & 46 & 2.65 & 2.57 & 1.03 & 5.0 & 1.2 & .4 .2 & 5 & 6.1 \\
\hline 22 & V.S. & Nephritis, chronic & 27 & - & - & - & 4.8 & 1.2 & 4.0 & 2 & 2.7 \\
\hline 23 & S. Ly. & Nephritis, chronic & 15 & 2.33 & 2.54 & 0.92 & 8.1 & 2.1 & 3.9 & 7 & 12.0 \\
\hline 24 & J. C. & Nephritis, chronic & 27 & 3.24 & 2.41 & 1.34 & 7.8 & 2.1 & 3.7 & 16 & 6.9 \\
\hline 25 & R. S. & Nephritis, chroniç & 31 & 2.59 & 2.39 & 1.08 & 9.8 & 2.9 & 3.4 & 17 & 4.1 \\
\hline 26 & C. A. & Nephritis, chronic & 34 & 3.48 & 2.89 & 1.20 & 4.4 & 1.3 & 3.4 & 12 & 5.4 \\
\hline 27 & M. H. A. & Nephritis, chronic & 20 & 3.09 & 2.31 & 1.34 & 5.0 & 1.6 & 3.1 & 7 & 3.4 \\
\hline 28 & H. L. & Nephritis, chronic & 10 & 2.67 & 2.32 & 1.15 & 5.3 & 1.7 & 3.1 & 2 & 8.4 \\
\hline 29 & F. M. & Nephritis, chronic & 13 & 2.62 & 2.79 & 0.94 & 3.4 & 1.1 & 3.1 & 4 & 10.0 \\
\hline
\end{tabular}

* Values for the blood pressure and for the amount of edma and transudates are those found on admission, except in case 24, in which there was a long hospital stay before the observations were made. The findings have been recorded in this way in order to give as definite a picture as possible of the clinical condition, before it had been modified by treatment. 


\begin{tabular}{|c|c|c|c|c|c|c|}
\hline $\begin{array}{l}\text { Average } \\
\text { blood urea } \\
\text { nitrogen } \\
\text { per liter }\end{array}$ & $\begin{array}{l}\text { Average } \\
\text { blood } \\
\text { creatinine } \\
\text { per } 100 \mathrm{cc} \text {. }\end{array}$ & $\underset{\text { pressure* }}{\text { Blood }}$ & $\begin{array}{c}\text { Peripheral } \\
\text { edema* }\end{array}$ & $\begin{array}{c}\text { Serous } \\
\text { effu- } \\
\text { sions* }\end{array}$ & $\begin{array}{l}\text { Duration of } \\
\text { life after last } \\
\text { observation }\end{array}$ & Remarks \\
\hline grams & $m g m$. & & & & & . \\
\hline 0.082 & 1.36 & $118 / 68$ & ++ & + & - & Seen 13 months later; very edematous \\
\hline 0.124 & 1.60 & $126 / 70$ & + & 0 & - & No worse 15 months later \\
\hline 0.060 & 1.15 & $110 / 76$ & ++ & ++ & - & Perfectly well 3 years later \\
\hline 0.151 & 1.53 & $120 / 78$ & ++ & $\mathbf{0}$ & - & No worse 19 months later \\
\hline 0.081 & - & $108 / 70$ & ++ & ++ & - & No worse 18 months later \\
\hline 0.072 & - & $110 / 70$ & $+++t$ & ++ & 4 days & \\
\hline 0.065 & 1.58 & $146 / 88$ & ++ & ++ & - & $\begin{array}{l}\text { Still edematous } 16 \text { months later. Had } \\
\text { lost ground }\end{array}$ \\
\hline 0.167 & 1.36 & $130 / 65$ & + & $\mathbf{0}$ & - & Not traced \\
\hline 0.233 & 1.57 & $160 / 92$ & + & ++ & - & Seemed recovered 15 months later \\
\hline 0.193 & 1.87 & $160 / 106$ & ++ & +++ & - & Considerable improvement a year later \\
\hline 0.082 & 1.55 & $108 / 74$ & 0 & $\mathbf{0}$ & - & \\
\hline 0.139 & 1.59 & $148 / 76$ & + & $\mathbf{0}$ & - & Discharged unimproved 7 months later \\
\hline 0.280 & 1.84 & $164 / 90$ & + & $\mathbf{0}$ & - & Condition stationary 15 months later \\
\hline 0.153 & 1.62 & $166 / 98$ & ++ & 0 & 9 months & Progress unfavorable. Died of diphtheria \\
\hline 0.218 & 2.01 & $150 / 92$ & ++ & \pm & 6 months & Death probably from general septicemia \\
\hline 0.235 & 1.40 & $138 / 80$ & ++ & 0 & $\cdot-$ & $\begin{array}{l}\text { Seen } 16 \text { months later } \\
\text { Kidney function worse but clinically better }\end{array}$ \\
\hline 0.180 & 1.64 & $138 / 92$ & ++ & + & 17 months & $\begin{array}{l}\text { Death from uremia and heart failure. } \\
\text { Autopsy }\end{array}$ \\
\hline 0.124 & 1.37 & $100 / 70$ & ++ & + & 18 months & Death from uremia and asthenia \\
\hline 0.154 & 1.36 & $134 / 78$ & ++ & +++ & 11 months & Death from uremia and heart failure \\
\hline 0.346 & 1.31 & $120 / 60$ & + & 0 & - & $\begin{array}{l}\text { Observed for } 2 \text { years. Progress un- } \\
\text { favorable }\end{array}$ \\
\hline 0.369 & 6.10 & $270 / 120$ & ++ & + & 1 month & $\begin{array}{l}\text { Edema and hydrothorax relieved by digi- } \\
\text { talis. Death from cardiac decompen- } \\
\text { sation }\end{array}$ \\
\hline 0.292 & 2.52 & $250 / 92$ & +++ & \pm & 7 months & Died in coma (from cerebral edema?) \\
\hline 1.548 & 24.73 & $206 / 126$ & 0 & 0 & 3 days & Death from uremia \\
\hline 0.280 & - & $158 / 95$ & 0 & 0 & - & Free from symptoms 3 years later \\
\hline 1.700 & 16.60 & $190 / 130$ & + & 0 & 21 days & Death from uremia \\
\hline 0.658 & 7.33 & $156 / 100$ & ++ & + & 3 months & Death from uremia \\
\hline 0.733 & 5.20 & $225 / 114$ & $\begin{array}{l}\text { Very } \\
\text { slight }\end{array}$ & 0 & few.weeks & \\
\hline 0.794 & 6.09 & $162 / 118$ & +++ & ++ & 2 months & $\begin{array}{l}\text { Cardiac edema. Death from cardiac de- } \\
\text { compensation }\end{array}$ \\
\hline 0.440 & - & $120 / 90$ & + & + & 6 months & Death from uremia \\
\hline 0.200 & 1.67 & $208 / 145$ & ++ & ++ & 7 months & Died of pneumonia \\
\hline
\end{tabular}

When the amount of peripheral edema exceeded a slight pitting it has been recorded in degrees, on a scale of 4. The record for transudates is similarly represented. The symbol \pm is used to record the fact of a slight amount of dullness in the flanks, or impairment of resonance at the lung bases, when the actual presence of fluid could not be definitely substantiated. 
urea concentration indices in these cases, and the majority of cases with ratios under 5 had urea concentration indices under 15 .

TABLE 5

Case 10, acute nephritis, showing increase in albumin: globulin ratio during period of recovery

\begin{tabular}{|c|c|c|c|c|c|c|c|c|c|}
\hline \multirow[b]{2}{*}{ Date } & \multicolumn{4}{|c|}{ Urine } & \multicolumn{4}{|c|}{ Blood plasma } & \multirow[b]{2}{*}{ Remarks } \\
\hline & 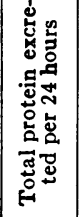 & 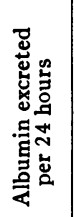 & 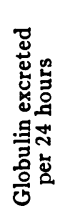 & 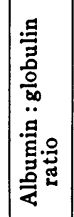 & 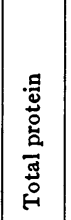 & 章 & $\begin{array}{l}\frac{9}{3} \\
\frac{0}{0} \\
\frac{0}{6}\end{array}$ & 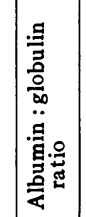 & \\
\hline 1925 & grams & grams & grams & & \begin{tabular}{|c|} 
per \\
cent
\end{tabular} & $\begin{array}{c}\text { per } \\
\text { cent }\end{array}$ & $\begin{array}{c}\text { per } \\
\text { cent }\end{array}$ & & \\
\hline January 11 & 16.1 & 13.8 & 2.3 & 6.0 & 4.70 & 1.59 & 3.11 & 10.51 & $\begin{array}{l}\text { Period of apparently sta- } \\
\text { tionary condition }\end{array}$ \\
\hline January 12 & 16.4 & 15.1 & 2.4 & 6.3 & & & & & \\
\hline January 19 & 20.7 & 16.4 & 4.3 & 3.8 & 3.65 & 1.30 & 2.35 & 50.55 & \\
\hline January 26 & 18.5 & 15.8 & 2.7 & 5.9 & & & & & \\
\hline February 1 & 20.1 & 16.1 & 4.0 & 4.0 & & & & & \\
\hline February 12 & 23.3 & 14.1 & 2.3 & 6.1 & & & & & \\
\hline February 24 & 7.3 & 6.0 & 1.3 & 4.6 & 4.09 & 1.54 & 2.55 & $5 \mid 0.60$ & Profuse diuresis began, \\
\hline February 25 & 6.4 & 5.3 & 1.1 & 4.8 & & & & & $\begin{array}{l}\text { with loss of edema and } \\
\text { with general improve- } \\
\text { ment }\end{array}$ \\
\hline \multicolumn{4}{|c|}{ Average...$\ldots \ldots \ldots \ldots \ldots$} & 5.2 & & & & 0.55 & \\
\hline March 29 & 10.3 & 9.1 & 1.2 & 7.6 & 5.19 & $2.45 \mid$ & 2.75 & 50.89 & \multirow[t]{6}{*}{ Period of recovery } \\
\hline March 31 & 9.7 & 9.0 & 0.7 & 12.9 & & & & & \\
\hline April 8 & 8.8 & 7.4 & 1.4 & 5.3 & 5.29 & 2.36 & 2.93 & 30.81 & \\
\hline April 15 & 7.7 & 6.9 & 0.8 & 8.6 & & & & & \\
\hline April 28 & 4.9 & 4.5 & 0.4 & $\mid 11.2$ & & & & & \\
\hline April 29 & 7.7 & 7.2 & 0.5 & 14.4 & & & & & \\
\hline Average.. & & & & 10.0 & & & & 0.85 & \\
\hline
\end{tabular}

The correlation between excretion of protein in the urine and loss of protein in the blood plasma is shown in table 6 and figure 3. From the point of view of total protein lost, table 6 shows a general decrease 
of total plasma protein with increase in the total protein excretion when the averages of protein excretion from a number of cases are considered. This finding is consistent with others in the literature, discussed previously.

In attempting to correlate the albumin : globulin ratio in the blood plasma with that in the urine, shown by figure 3 , it can be said, in a general way, that the cases of nephrosis, area $\mathrm{A}$, with high urine

TABLE 6

Relation of total protein in the urine to total protein in the blood plasma

\begin{tabular}{c|c|c|c}
\hline \multirow{2}{*}{$\begin{array}{c}\text { Number of cases } \\
\text { observed }\end{array}$} & Plasma & \multicolumn{2}{|c}{ Total protein } \\
\cline { 2 - 4 } & Range & Range per 24 hours & Average per 24 hours \\
\cline { 2 - 4 } & per cent & grams & grams \\
1 & $6-7$ & & 5.3 \\
11 & $5-6$ & $1.6-12.0$ & 5.8 \\
10 & $4-5$ & $1.3-16.1$ & 8.6 \\
7 & $3-4$ & $3.3-16.3$ & 9.8 \\
\hline
\end{tabular}

TABLE 7

Relation between albumin : globulin ratio in urine and duration of life

\begin{tabular}{|c|c|c|c|c|}
\hline & $\begin{array}{c}\text { Total } \\
\text { number } \\
\text { of cases }\end{array}$ & $\begin{array}{l}\text { Number } \\
\text { still } \\
\text { living }\end{array}$ & Number & Remarks \\
\hline $\begin{array}{l}\text { Cases with average } \mathrm{A}: \mathrm{G} \text { ratio ex- } \\
\text { ceeding } 10 \ldots \ldots \ldots \ldots \ldots \ldots \ldots\end{array}$ & 4 & 4 & 0 & \\
\hline $\begin{array}{l}\text { Cases with average } A: G \text { ratio between } \\
5 \text { and } 10 \ldots \ldots \ldots \ldots \ldots \ldots \ldots\end{array}$ & 9 & 6 & 2 & One case untraced \\
\hline Cases with average $A: G$ ratio under 5 & 16 & 3 & 13 & $\begin{array}{l}\text { Average duration of life } \\
\text { in fatal cases } 6 \text { months }\end{array}$ \\
\hline
\end{tabular}

albumin : globulin ratios, tend to have lower plasma ratios, while the cases of chronic nephritis, area $\mathrm{C}$, with low urine ratios tend to have the higher plasma ratios: the greater the proportion of albumin in the urinary protein loss the greater tends to be the albumin deficit in the blood plasma. The cases of acute nephritis, area $B$, fall irregularly between areas $\mathrm{A}$ and $\mathrm{C}$. Case 10 shows the changes which occurred during recovery, from a low ratio in both urine and 
plasma in the initial stages to higher ratios in the stage of recovery. In this case the above general rule is reversed; urinary and plasma albumin : globulin ratios showed a parallel instead of a reverse change. Case 6, with nephrosis and amyloidosis, is also an exception. The plasma and urine ratios are both lower than any others observed.

The general tendency towards an inverse relation between plasma and urine ratios would seem to point to excretion of one type of protein in the urine as at least a partial explanation for the loss of that protein in the plasma. In view of the deviations, however, it appears that other factors in addition to protein excretion are involved in the process of lowering the plasma proteins.

An attempt was made to correlate changes in the amount of protein excretion with changes in the volume of urine excreted, by recording daily excretions, 12 -hour excretions, and hourly excretions. The results showed sometimes an increased protein excretion with increased volume, at other times no relationship, and, on a few occasions, the opposite effect.

The prognostic significance of the albumin : globulin ratio in the urine is shown in tables 4 and 7 . Of the 4 cases with average ratios exceeding 10 , one has recovered completely, while the remaining three show no signs of downward progress since the time of the original observations, which covers periods varying from 13 to 19 months (table 4).

Of the 9 cases whose average albumin : globulin ratio in the urine fell between 5 and 10, two (nos. 13 and 14) have died. In both cases death was due to intercurrent infection, and cannot be ascribed to disease of the kidneys. None of the cases in the group have developed serious impairment of kidney function.

Of the 16 cases with average ratios under 5,13 died within from 3 days to 18 months after the observations were made. One of these cases (no. 23) was seen a year later and had lost ground. He is still living and free from symptoms 3 years after the observation. The two remaining cases have been examined from time to time. Both of these (nos. 15 and 19) have shown a downward progress and kidney function is becoming progressively more impaired.

Each tabulated urinary albumin : globulin ratio is the average of estimations made on a number of different days. The range of 
values for the ratios found during the period of observation, as well as the averages, are shown in figure 2. The variations from day to day in the ratios of some of the cases were fairly large.

This variation and the consequent overlapping shown in figure 2 are sufficiently great to invalidate conclusions from any single determination. The average of several days is required. The variations appear due to actual fluctuations in the proportions of albumin and globulin excreted, and not to errors in technique.

\section{SUMMARY}

The albumin and globulin in nephritic urines have been separated with Howe's sodium sulfate procedure, the separated proteins being determined by a modification of Autenrieth's colorimetric use of the biuret protein reaction. A satisfactory standard for this method has been found in pure biuret.

The albumin: globulin ratio of the urine proteins was found usually above 10 in nephrosis; between 5 and 10 in acute nephritis, with a low ratio during the early stage followed by a higher ratio during recovery; usually below 5 in the advanced stages of chronic glomerular nephritis with urea retention and impaired kidney function. In one case of amyloid nephrosis the ratio was very low, 1.5, in accord with the previous literature.

The low ratios in advanced chronic nephritis were associated with low urea concentration indices and poor prognoses. Of 15 cases observed with average urinary albumin : globulin ratios below 5, all but 2 have died in less than 18 months, and these 2 have shown progressive decrease in renal function.

\section{BIBLIOGRAPHY}

1. Senator, H., Die Erkrankungen der Nieren. Wien, 1896, [Alfred Hölder].

2. Cloëtta, M., Arch. f. exp. Path. u. Pharm., 1899, xlii, 453. Ueber die Genese der Eiweisskörper bei der Albuminurie.

3. Geill, T., Ugeskr. f. Laeger, 1926, lxxxviii, 838. Om Albuminuri specielt om Forholdet mellem Albumin og Globulin i Urinen.

4. Hoffman, F. A., Virchow's Arch. f. Path. Anat. u. Physiol. u. f. klin. Med., 1882, lxxxix, 271. Ueber das Verhältniss zwischen Serumalbumin und Globulin im eiweissführenden Harn. 
5. Lecorché, E., and Talamon, C., Traité de l'albuminurie et du mal de Bright, Paris, 1888, [Doin].

6. Csatáry, A., Deut. Arch. f. klin. Med., 1891, xlvii, 159. Ueber Globulinurie. I.

Csatáry, A., Deut. Arch. f. klin. Med., 1891, xlviii, 358. Ueber Globllinurie. II.

7. Joachim, J., Arch. f. d. ges. Physiol., 1903, xciii, 558. Ueber die Eiweissvertheilung in menschlichen und thierischen Körperflüssigkeiten.

8. Paton, D. N., Brit. Med. J., 1890, ii, 197. Observations on the Proportions of the Chief Proteids Occurring in the Urine in Various Forms of Albuminuria.

9. Dreser, H., Schmidts' Jahrbücher d. ges. Medicin, 1902, cclxxvi, 117. Originalabhandlungen und Uebersichten. Ueber physiologische Albuminurie.

10. Gross, O., Deut. Arch. f. klin. Med., 1906, lxxxvi, 578. Über die Eiweisskörper des eiweisshaltigen Harns.

11. Strauss, H., Centr. f. inn. Med., 1916, xxxvii, 201. Zur genaueren Unterscheidung der renalen Albuminurien nebst Bemerkungen über "Kriegsnephritiden."

12. Wallis, R. L. M., Proc. Roy. Soc. Med., 1919-20, xiii, Med. Sect., 96. Nonnephritic Albuminuria.

13. Autenrieth, W., Münch. Med. Woch., 1917, lxiv, 241. Ueber kolorimetrische Bestimmungsmethoden: Die Bestimmung von Serumalbumin und Globulin im Harn, in der Aszitesflüssigkeit und im Blutserum.

14. Kisch, F., Klin. Woch., 1922, i, 848. Eiweisskonzentration und Chlornatriumabsorptionsvermögen der Blutserums Ödematöser.

15. Linder, G. C., Lundsgaard, C., and Van Slyke, D. D., J. Exp. Med., 1924, xxxix, 887. The Concentration of the Plasma Proteins in Nephritis.

16. Kollert, V., and Starlinger, W., Zeit. f. klin. Med., 1926, civ, 44 . Ueber das Verteilungsverhältnis der Eiweisskörpergruppen des Blutplasmas und Harnes bei Nierenkranken.

17. Howe, P. E., J. Biol. Chem., 1921, xlix, 93. The Use of Sodium Sulfate as the Globulin Precipitant in the Determination of Proteins in Blood.

Howe, P. E., J. Biol. Chem., 1921, xlix, 109. The Determination of Proteins in Blood-a Micro Method.

18. Autenrieth, W., and Mink, F., Münch. Med. Woch., 1915, lxii, 1417. Ueber kolorimetrische Bestimmungsmethoden: die quantitative Bestimmung von Harneiweiss.

19. Haslam, H. C., Biochem. J., 1913, vii, 492. Separation of Proteins. III. Globulins.

20. Van Slyke, D. D., and Cullen, G. E., J. Biol. Chem., 1914, xix, 211. A Permanent Preparation of Urease, and Its Use in the Determination of Urea. 
Van Slyke, D. D., and Cullen, G. E., J. Biol. Chem., 1916, xxiv, 117. The Determination of Urea by the Urease Method.

21. Folin, O., and Wu, H., J. Biol. Chem., 1919, xxuviii, 81. A System of Blood Analysis.

22. Van Slyke, D. D., Linder, G. C., Hiller, A., Leiter, L., and McIntosh, J. F., J. Clin. Invest., 1926, ii, 255. The Excretion of Ammonia and Titratable Acid in Nephritis.

23. Senator, H., Virchow's Arch. f. path. Anat. u. Physiol. u. f. klin. Med., 1874, Ix, 476. Ueber die im Harn vorkommenden Eiweisskörper und die Bedingungen ihres Auftretens bei den verschiedenen Nierenkrankheiten, über Harncylinder und Fibrinausschwitzung. 